\section{Effects of Foliar Applications of Smoke-Water and a Smoke-isolated Butenolide on Seedling Growth of Okra and Tomato}

\author{
Manoj G. Kulkarni, Glendon D. Ascough, and Johannes Van Staden ${ }^{1}$ \\ Research Centre for Plant Growth and Development, School of Biological \\ and Conservation Sciences, University of KwaZulu-Natal Pietermaritzburg \\ Private Bag X01, Scottsville 3209, South Africa
}

Additional index words. seedling vigor, smoke solutions, spraying, vegetable crops

\begin{abstract}
The ecologic significance of smoke-related seed germination is now well recognized. Consequently, smoke solutions and a pure butenolide, the active compound from smoke that stimulates germination of a number of plant species, show great potential for enhancing the growth of vegetable crops. Achieving maximum production and better and faster growth of the seedlings has always been a priority for vegetable growers. This study therefore highlights the effects of foliar application of smoke-water and a butenolide on seedling growth of okra [Abelmoschus esculentus (L.) Moench] and tomato (Lycopersicon esculentum Mill.). Treating okra seedlings with smoke-water (1:500 v/v) showed a significant $(P<0.05)$ increase in shoot/root length, shoot fresh/dry weight, number of leaves, total leaf area, and stem thickness compared with the control treatment. Treatment of okra seedlings with smoke-water significantly $(P<0.05)$ increased the absolute growth rate (AGR) per week. However, the seedling vigor index (SVI) did not improve as a result of no change in root fresh weight. On the other hand, foliar application of smoke-water and butenolide showed a pronounced effect on the seedling growth of tomato. Most of the growth parameters examined for both the treatments were significantly $(P<0.05)$ increased, resulting in a significantly $(P<0.05)$ higher SVI and AGR than the control. This study indicates that the foliar application of smoke-water or butenolide may be a useful and inexpensive technique for enhancing seedling growth of vegetable crops.
\end{abstract}

In traditional farming systems, the burning of fields was a common practice that alleviated the infestation of noxious weeds and insects (Altieri, 1993). Apparently, smoke as a consequence of burning is being used directly or indirectly by subsistence farmers for drying and storing grain. The general belief is that exposing these grains to smoke gives them protection against insect and microbial attack (De Groot, 1996). Interestingly, some studies report that this indigenous method influences germination rate and stimulates seedling vigor of these grains (Modi, 2002; Paasonen et al. 2003). In other studies, smoke-treated seeds of some vegetable crops such as lettuce (Drewes et al., 1995) and celery (Thomas and Van Staden, 1995) have also shown enhanced germination. A recent investigation by Van Staden et al. (2006) showed that treating seeds of tomato, okra, and bean with smoke-water and a butenolide isolated

\footnotetext{
Received for publication 28 July 2006. Accepted for publication 20 Sept. 2006

The financial support of the National Research Foundation (NRF), Pretoria, and the University of KwaZulu-Natal Research Fund is gratefully acknowledged.

${ }^{1}$ To whom reprint requests should be addressed; e-mail rcpgd@ukzn.ac.za.
}

from smoke (Flematti et al., 2004; Van Staden et al., 2004) significantly improved the seedling vigor of these vegetables. Studies have indicated that smoke functions like a plant hormone (Gardner et al., 2001; Senaratna et al., 1999; Van Staden et al., 2000) and the promontory action of smokewater could be the result of the presence of a butenolide, which presumably acts like other known plant growth regulators (Van Staden et al., 2006). However the exact physiological or biochemical action remains unknown.

It has been suggested that smoke can possibly be used in promoting the growth of horticulture and vegetable crops (Brown and Van Staden, 1998; Light and Van Staden, 2004). Particularly in vegetable crop production, maximum yield is achieved when there is a better emergence and stand establishment of the seedlings (Grassbaugh and Bennett, 1998). Staggered emergence results in seedlings of different sizes, which can develop into a heterogeneous crop (Bennett et al., 1992). During the early developmental stages, the seedlings are often exposed to several factors, which can result in poor seedling growth affecting the yield of the crop; these include temperature fluctuations, poor soil structure, insufficient nutrient availability, soil salinity, and water stress (Orzolek, 1991). To overcome these unavoidable stresses, the seeds are presoaked in water, micronutrients, or growth regulators. Subsequently, when the seedlings emerge and the leaves develop, they are supplemented with foliar nutrients (Fernández and Ebert, 2005; Nowosielski et al., 1988) or growth-promoting substances (Murillo-Amador et al., 2005; Nonomura and Benson, 1992). The general concept of foliar application is that the absorption of nutrients by the leaf is much quicker than from the soil, which eventually reduces the lag time between application and uptake by the plant (Taiz and Zeiger, 1991).

Recent studies on maize (Sparg et al., 2006) and vegetables (Van Staden et al., 2006) have shown that smoke-treated seeds of these crops can be transformed into vigorous seedlings indicating the possible use of smoke technology in crop production. Thus, in an attempt to produce good-quality vegetable seedlings (Minami, 2003), this study was conducted to determine the effects of smoke-water and a smoke-isolated compound, butenolide [3-methyl- $2 H$-furo(2,3c)pyran-2-one] (Van Staden et al., 2004), on seedling growth of two popular vegetables, okra and tomato.

\section{Materials and Methods}

Trials were conducted on commercial seeds of okra [Abelmoschus esculentus (L.) Moench. 'Clemson Spineless'] and tomato (Lycopersicon esculentum Mill. 'Heinz1370') purchased from McDonald's Seed Company, Pietermaritzburg, South Africa. The experiment was set up on 8 Mar. 2006 in a greenhouse at $20 \pm 2{ }^{\circ} \mathrm{C}$ having midday photosynthetic radiation of $400 \pm 85$ $\mu \mathrm{mol} \cdot \mathrm{m}^{-2} \cdot \mathrm{s}^{-1}$. Plastic pots $(500 \mathrm{~mL})$ were filled with a soil mixture (1 compost : 1 garden soil, by volume) and one seed per pot was sown at a depth of $1 \mathrm{~cm}$. Pots were watered until they reached field capacity.

An aqueous smoke extract was prepared by uninterrupted bubbling of smoke from smoldering Themeda triandra Forssk. (Poaceae) leaf material through $500 \mathrm{~mL}$ water for 45 min (Baxter et al., 1994). Smoke-water $(1: 500 \mathrm{v} / \mathrm{v})$ was prepared by diluting $1 \mathrm{~mL}$ of above aqueous smoke extract to $500 \mathrm{~mL}$ with distilled water. The butenolide [3-methyl- $2 \mathrm{H}$ furo(2,3-c)pyran-2-one] was isolated from plant-derived smoke according to the method outlined in Van Staden et al. (2004) and 0.1 $\mu \mathrm{M}$ concentration solution was used.

Foliar treatment consisted of spraying okra and tomato seedlings with water (control), smoke-water, or butenolide solution. Before spraying, one drop of Tween 20 as a surfactant was added to $250 \mathrm{~mL}$ test solution, including control. The stem and leaves of young seedlings were treated by spraying $(500-\mathrm{mL}$ handheld spray bottle was used) the previously mentioned solutions to the point of runoff on 16, 20, 24, and 28 Mar. 2006. After the first foliar application, the pots were arranged randomly on the benches 
in a greenhouse. Each treatment had 25 pots and every single pot was considered a replicate. The pots were watered three times per week. Matured seedlings (young plants) were harvested on 5 Apr. 2006 and growth parameters were recorded. Stem thickness was measured using vernier calipers, whereas the leaf area was measured with an area meter (LI-3100; LI-COR Inc., Lincoln, Nebr.). The seedling vigor index (SVI) was calculated on the basis of the following formula (Rui-June, 1987): SVI = [stem thickness $(\mathrm{mm}) /$ seedling length $(\mathrm{mm})+$ root fresh weight $(\mathrm{g}) /$ shoot fresh weight $(\mathrm{g})] \times[$ shoot fresh weight $(\mathrm{g})+$ root fresh weight $(\mathrm{g})]$. The average absolute growth rate (AGR) was calculated as: $\mathrm{AGR}=\mathrm{W} / \mathrm{T}$, where $\mathrm{W}$ is the total increase in weight and $\mathrm{T}$ is the time of measurement (Clipson, 1994). Dry weight of shoots and roots were recorded after drying them at $70{ }^{\circ} \mathrm{C}$ for $7 \mathrm{~d}$.

Statistical analysis was conducted using MINITAB statistical package, release 12.1 (MINITAB Inc., State College, Pa.). The data gathered from the trials were subjected to one-way analysis of variance and Fisher pairwise comparisons at a 5\% level of significance were performed.

\section{Results}

Foliar spraying of smoke-water on okra seedlings resulted in significantly $(P<0.05)$ longer shoot and root lengths (157 and 184 $\mathrm{mm}$, respectively) than the control seedlings (145 and $133 \mathrm{~mm}$, respectively) (Fig. 1A, B). The seedlings also showed a significant increase in shoot fresh weight $(6.2 \mathrm{~g})$, number of leaves (3.4), and leaf area $\left(101 \mathrm{~cm}^{2}\right)$ in comparison with controls (Fig. 1C, E, F). Smoke-water treatment of okra seedlings significantly increased stem thickness, shoot dry weight, and AGR compared with the control (Table 1). However, the root dry weight and SVI were not significantly $(P>$ 0.05 ) improved. Although foliar application of butenolide on okra seedlings showed higher values for most of the growth parameters (Fig. 1 and Table 1), these values were not significantly different from the control seedlings.

In the case of tomato seedlings, foliar application of smoke-water significantly increased shoot and root lengths (107 and 186 $\mathrm{mm}$, respectively) compared with the control (Fig. 2A, B). Although butenolide-treated seedlings had longer shoots and roots than the control, these results were not significantly different. Treating tomato seedlings with smoke-water significantly increased the maximum shoot fresh weight $(4.4 \mathrm{~g})$, whereas butenolide treatment had a significantly greater root fresh weight $(713 \mathrm{mg})$ than the control (Fig. 2C, D). On the other hand, smoke-water and butenolide treatments showed significantly higher shoot and root dry weights than control (Table 1). In comparison with the control, the number of leaves and total leaf area were significantly greater when tomato seedlings had foliar treatment
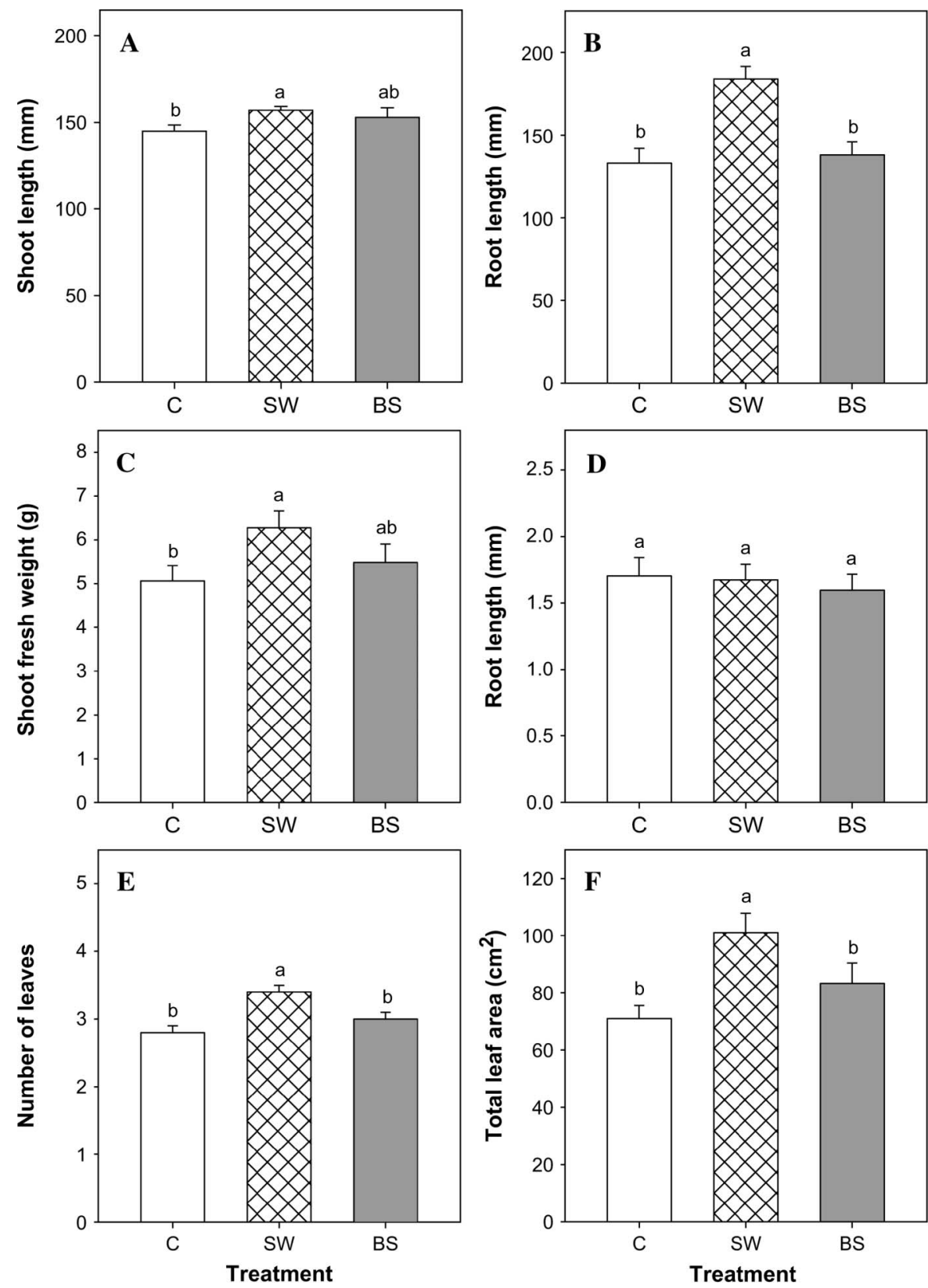

Fig. 1. (A-F) Effect of foliar application of water (C, control), smoke-water (SW, 1:500 v/v), and smokeisolated butenolide solution (BS, $0.1 \mu \mathrm{M}$ ) on seedling growth parameters of okra under greenhouse conditions. Standard error bars in each growth parameter with different letter(s) are significantly different at $P<0.05$ by Fisher's least significant difference procedure.

Table 1. The effect of foliar applications of smoke-water $(1: 500 \mathrm{v} / \mathrm{v})$ and smoke-isolated butenolide $(0.1$ $\mu \mathrm{M})$ on seedling growth parameters of okra and tomato under greenhouse conditions.

\begin{tabular}{lccccc}
\hline Treatment & $\begin{array}{c}\text { Stem thickness } \\
(\mathrm{mm})\end{array}$ & $\begin{array}{c}\text { Shoot dry } \\
\text { wt }(\mathrm{mg})\end{array}$ & $\begin{array}{c}\text { Root dry } \\
\mathrm{wt}(\mathrm{mg})\end{array}$ & $\begin{array}{c}\text { Seedling vigor } \\
\text { index }\end{array}$ & $\begin{array}{c}\text { Absolute growth } \\
\text { rate }\left(\mathrm{mg} \cdot \text { week }^{-1}\right)\end{array}$ \\
\hline Okra & & & & & \\
$\quad$ Control & $4.41 \pm 0.16 \mathrm{~b}$ & $515 \pm 36.0 \mathrm{~b}$ & $150 \pm 18.0 \mathrm{a}$ & $2.394 \pm 0.209 \mathrm{a}$ & $166 \pm 12 \mathrm{~b}$ \\
$\quad$ Smoke-water & $4.98 \pm 0.18 \mathrm{a}$ & $656 \pm 45.0 \mathrm{a}$ & $142 \pm 12.2 \mathrm{ab}$ & $2.244 \pm 0.174 \mathrm{a}$ & $199 \pm 10 \mathrm{a}$ \\
$\quad$ Butenolide & $4.75 \pm 0.19 \mathrm{ab}$ & $606 \pm 45.0 \mathrm{ab}$ & $111 \pm 7.00 \mathrm{~b}$ & $2.174 \pm 0.176 \mathrm{a}$ & $179 \pm 11 \mathrm{ab}$ \\
$\begin{array}{c}\text { Tomato } \\
\quad \text { Control }\end{array}$ & $4.10 \pm 0.10 \mathrm{a}$ & $223 \pm 19.8 \mathrm{~b}$ & $33.8 \pm 3.1 \mathrm{~b}$ & $0.624 \pm 0.042 \mathrm{~b}$ & $64 \pm 5 \mathrm{~b}$ \\
$\quad$ Smoke-water & $4.38 \pm 0.21 \mathrm{a}$ & $360 \pm 27.9 \mathrm{a}$ & $53.4 \pm 3.6 \mathrm{a}$ & $0.870 \pm 0.058 \mathrm{a}$ & $103 \pm 6 \mathrm{a}$ \\
$\quad$ Butenolide & $4.41 \pm 0.10 \mathrm{a}$ & $356 \pm 24.2 \mathrm{a}$ & $59.0 \pm 4.2 \mathrm{a}$ & $0.915 \pm 0.071 \mathrm{a}$ & $103 \pm 5 \mathrm{a}$ \\
\hline
\end{tabular}

Data are the means of 25 replicates \pm SE. Values in the column for okra or tomato with different letter(s) are significantly different at $P<0.05$ by Fisher's least significant difference procedure.

of smoke-water and butenolide solution (Fig. 2E, F). However, these treatments showed nonsignificant increases in stem thickness (Table 1). Foliar spraying of tomato seedlings with smoke-water and butenolide significantly enhanced the SVI and AGR compared with the seedlings sprayed with water (Table 1). 

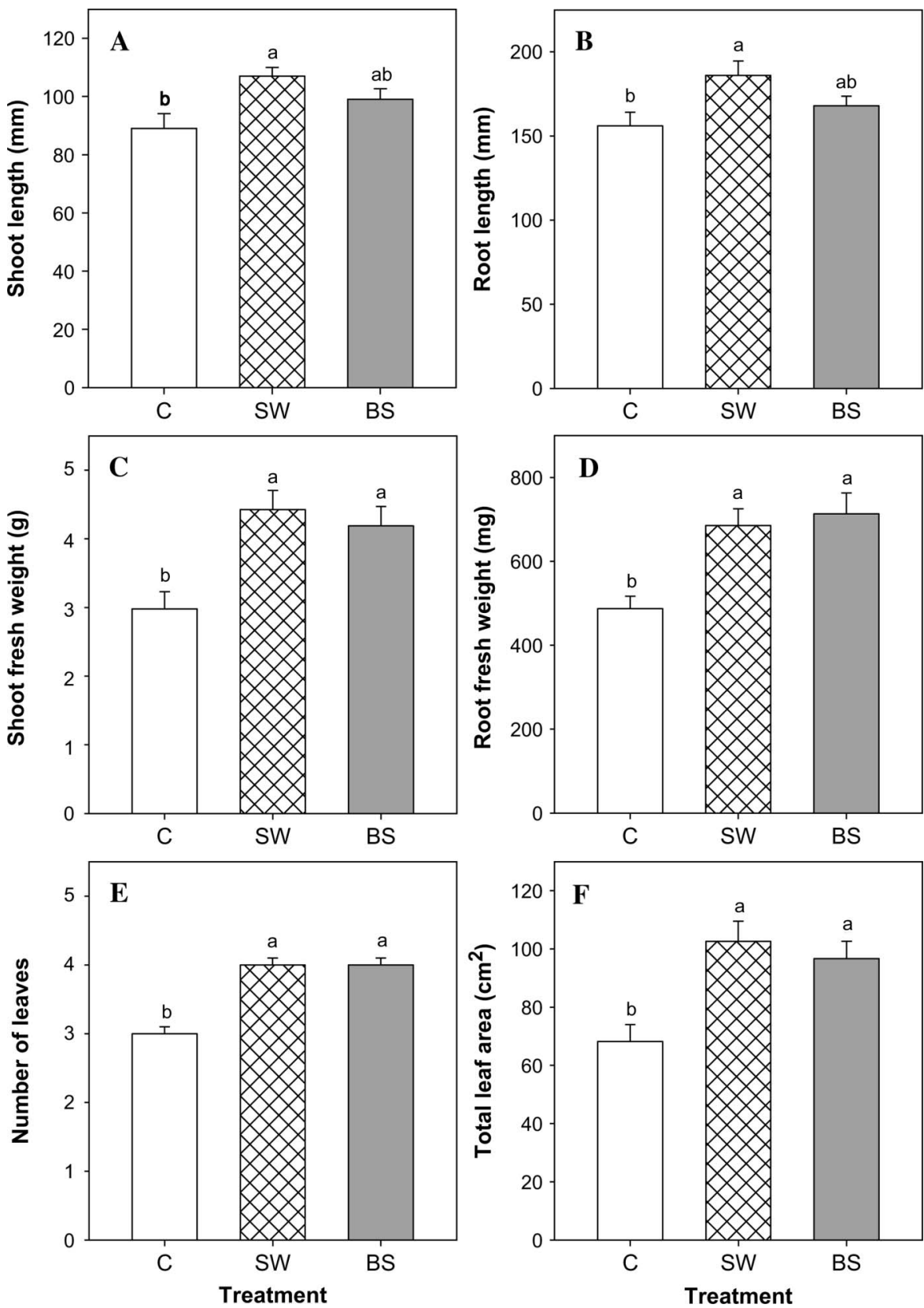

Fig. 2. (A-F) Effect of foliar application of water (C, control), smoke-water (SW, 1:500 v/v), and smokeisolated butenolide solution (BS, $0.1 \mu \mathrm{M})$ on seedling growth parameters of tomato under greenhouse conditions. Standard error bars in each growth parameter with different letter(s) are significantly different at $P<0.05$ by Fisher's least significant difference procedure.

\section{Discussion}

Results from this study show that okra seedlings responded positively to smokewater foliar applications. With the exception of root fresh and dry weight, all the other growth parameters of the seedlings showed a significant increase. Despite this, smoke-water treatments did not improve SVI but significantly increased AGR compared with untreated seedlings (Table 1). This is because the root fresh weight, a component of SVI, was not improved. It is therefore suggested that in addition to a foliar application, a soil drench with smoke-water would assist in enhancing the root system of okra seedlings. It was reported that aqueous extracts of smoke stimulate root initiation of mung beans (Taylor and Van Staden, 1996). Although in most of the cases, butenolide augmented the seedling growth of okra, this was not result therefore indicates that the stimulatory effect of butenolide on okra seedlings may be concentration-dependent. In this trial, only one concentration level was tested, and this could be one of the reasons that butenolide treatment, despite having higher values, did not significantly improve seedling growth. Smoke-water $(1: 500 \mathrm{v} / \mathrm{v})$ significantly different from the control. This promoted the growth of okra seedlings; however, the exact concentration of butenolide present in the smoke-water is not known at present.

Treating seedlings of tomato with smoke-water and butenolide showed better growth performance than the water controls. Both the treatments significantly enhanced fresh and dry weights of shoots and roots, leaf number, and total leaf area. High SVIs and AGRs clearly indicate that the seedlings of tomato show a positive response to smoke treatments. Recently, Van Staden et al. (2006) reported that butenolide-treated seeds of okra and tomato developed seedlings (6-day-old) with longer shoots than the untreated seeds. This difference was highly significant indicating that butenolide may be responsible for stimulating either cell elongation or division. In another study, Jain et al. (2006) showed that at low $\left(10{ }^{\circ} \mathrm{C}\right)$ and high $\left(40{ }^{\circ} \mathrm{C}\right)$ temperatures, seeds of tomato incubated with butenolide grew into phenotypically normal seedlings. In contrast, those incubated with water underwent radicle emergence but failed to grow further, although they were incubated for a prolonged period. Furthermore, Merritt et al. (2005) reports that horticultural species like celery, parsley, carrot, and leek show an increase in germination rate as well as maximal germination at suboptimal temperatures when treated with a butenolide isolated from smoke. This suggests that smoke-water or butenolide may play a significant role in alleviating the detrimental effects of low or high temperatures during the early phases of seedling growth.

In commerce, many vegetable crops are produced from transplanted seedlings, because this ensures improved uniformity and quality of the final product (NeSmith and Duval, 1998). To achieve optimal growth of the seedlings, they are supplied and sprayed with numerous nutrients, pesticides, and hormones, which ultimately increases production cost. Unfortunately, these applications are not always affordable to smallscale growers. Several benefits of applying smoke or its biologically active components to seeds have been demonstrated. In particular, a smoke-isolated butenolide has shown promising results. It is a stable compound, water-soluble, and remains active at very low concentrations, thus making it easy to use (Van Staden et al., 2006). In addition, it is reported that smoke constituents may have properties that protect the seed and seedlings against microbial attack (Roche et al., 1997). In this study, foliar applications of smoke-water clearly have a positive effect on the growth of okra and tomato seedlings (Fig. 3A, B), suggesting the beneficial use of smoke technology in raising healthy vegetable seedlings for transplanting. However, future research should attempt to find the right concentration of butenolide for promoting growth and field trials to determine the actual yield of a crop. 

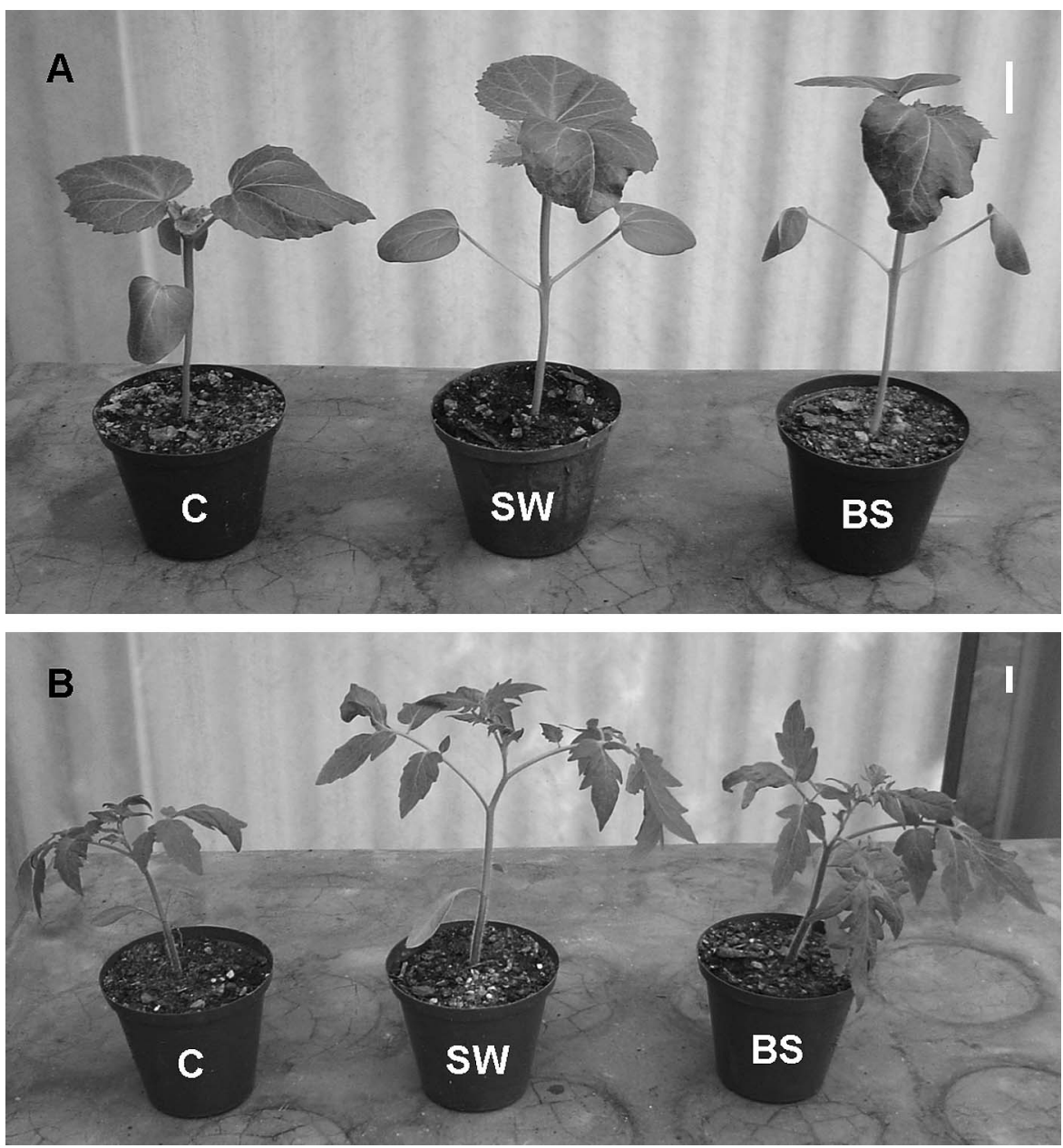

Fig. 3. Four-week-old foliar-treated seedlings of (A) okra and (B) tomato with water (C, control), smokewater $(\mathrm{SW}, 1: 500 \mathrm{v} / \mathrm{v})$, and butenolide solution (BS, $0.1 \mu \mathrm{M})$. Scale bars $(\mathbf{A})=35 \mathrm{~mm}$ and $(\mathbf{B}) 20 \mathrm{~mm}$.

\section{Literature Cited}

Altieri, M.A. 1993. Ethnoscience and biodiversity: Key elements in the design of sustainable pest management systems for small farmers in developing countries. Agr. Ecosys. Environ. 46:257-272.

Baxter, B.J.M., J. Van Staden, J.E. Granger, and N.A.C. Brown. 1994. Plant-derived smoke and smoke extracts stimulate seed germination of the fire-climax grass Themeda triandra. Environ. Exp. Bot. 34:217-223.

Bennett, M., V.A. Fritz, and N.W. Callan. 1992. Impact of seed treatments on crop stand establishment. HortTechnology 2:345-349.

Brown, N.A.C. and J. Van Staden. 1998. Plantderived smoke: An effective seed pre-soaking treatment for wildflower species and with potential for horticultural and vegetable crops. Seed Sci. Technol. 26:669-673.

Clipson, N.J.W. 1994. The measurement of growth, yield and productivity, p. 2-23. In: Biotechnology by Open Learning. Crop Productivity. Butterworth-Heinemann, Oxford, U.K.

De Groot, I. 1996. Protection of stored grains and pulses. 3rd ed. Agromisa Foundation, Agr. Univ. Wageningen, The Netherlands.

Drewes, F.E., M.T. Smith, and J. Van Staden. 1995. The effect of plant-derived smoke extract on the germination of light-sensitive lettuce seed. Plant Growth Regulat. 16:205-209.
Fernández, V. and G. Ebert. 2005. Foliar iron fertilization: A critical review. J. Plant Nutr. 28:2113-2124.

Flematti, G.R., E.L. Ghisalberti, K.W. Dixon, and R.D. Trengove. 2004. A compound from smoke that promotes seed germination. Science 305:977.

Gardner, M.J., K.J. Dalling, M.E. Light, A.K. Jäger, and J. Van Staden. 2001. Does smoke substitute for red light in the germination of light-sensitive lettuce seeds by affecting gibberellin metabolism? S. Afr. J. Bot. 67:636-640.

Grassbaugh, E.M. and M.A. Bennett. 1998. Factors affecting vegetable stand establishment. Scientia Agricola 55:116-120.

Jain, N., M.G. Kulkarni, and J. Van Staden. 2006. A butenolide, isolated from smoke, can overcome the detrimental effects of extreme temperatures during tomato seed germination. Plant Growth Regulat. (in press).

Light, M.E. and J. Van Staden. 2004. The potential of smoke in seed technology. S. Afr. J. Bot. 70:97-101.

Merritt, D.J., K.W. Dixon, G. Flematti, L.E. Commander, and S.R. Turner. 2005. Recent findings on the activity of butenolide-A compound isolated from smoke that promotes seed germination. Abstr. 8th Intl. Wkshp. on Seeds, p. 27, 8-13 May, Brisbane, Australia.
Minami, K. 2003. High quality of seedling in vegetable production. Acta Hort. 607:63 66

Modi, A.T. 2002. Indigenous storage method enhances seed vigour of traditional maize. S. Afr. J. Sci. 98:138-139.

Murillo-Amador, B., H.G. Jones, C. Kaya, and R.L. Aguilar, J.L. García-Hernández, E. TroyoDiéguez, N.Y. Ávila-Serrano, and E. RuedaPuente. 2005. Effects of foliar application of calcium nitrate on growth and physiological attributes of cowpea (Vigna unguiculata L. Walp.) grown under salt stress. Environ. Exp. Bot. 58:188-196.

NeSmith, D.S. and J.R. Duval. 1998. The effect of container size. HortTechnology 8:495-498.

Nonomura, A.M. and A.A. Benson. 1992. The path of carbon in photosynthesis: Improved crop yields with methanol. Proc. Natl. Acad. Sci. U S A 89:9794-9798.

Nowosielski, O., W. Dziennik, D. Kotlinska, J. Narkiewicz, and J. Dobrzanska. 1988. A biological basis for the efficiency of plant protecting foliar fertilizer in vegetable production. Acta Hort. 222:105-116.

Orzolek, M.D. 1991. Establishment of vegetables in the field. HortTechnology 1:78-81.

Paasonen, M., A. Hannukkala, S. Rämö, H. Haapala, and V. Hietaniemi. 2003. Smoke-A novel application of a traditional means to improve grain quality. Proc. 22nd Congr. Nordic Assn. Agr. Scientists, Turku, Finland. 20 June 2006. http://portal.mtt.fi/pls/portal30/ docs/PAGE/AGRONET/YHTEISET_ HANKKEET/NJF/NJF2003/10.PDF.

Roche, S., J.M. Koch, and K.W. Dixon. 1997. Smoke enhanced seed germination for mine rehabilitation in the southwest of Western Australia. Restor. Ecol. 5:191-203.

Rui-Jun, Z. 1987. Densities and media effect on tomato seedling quality. The Asian Vegetable Research and Development Center, Thailand. 20 June 2006. http://www.arc-avrdc.org/pdf files/Zhouruijun(5-N).pdf.

Senaratna, T., K. Dixon, E. Bunn, and D. Touchell. 1999. Smoke-saturated water promotes somatic embryogenesis in geranium. Plant Growth Regulat. 28:95-99.

Sparg, S.G., M.G. Kulkarni, and J. Van Staden. 2006. Aerosol smoke and smoke-water stimulation of seedling vigor of a commercial maize cultivar. Crop Sci. 46:1336-1340.

Taiz, L. and E. Zeiger. 1991. Plant Physiology. The Benjamin/Cummings Calif., U.S.

Taylor, J.L.S. and J. Van Staden. 1996. Root initiation in Vigna radiata (L.) Wilczek hypocotyl cuttings is stimulated by smoke-derived extracts. Plant Growth Regulat. 18:165 168.

Thomas, T.H. and J. Van Staden. 1995. Dormancy break of celery (Apium graveolens L.) seeds by plant derived smoke extract. Plant Growth Regulat. 17:195-198.

Van Staden, J., N.A.C. Brown, A.K. Jäger, and T.A. Johnson. 2000. Smoke as germination cue. Plant Species Biol. 15:167-178.

Van Staden, J., A.K. Jäger, M.E. Light, and B.V. Burger. 2004. Isolation of the major germination cue from plant-derived smoke. S. Afr. J. Bot. 70:654-659.

Van Staden, J., S.G. Sparg, M.G. Kulkarni, and M.E. Light. 2006. Post-germination effects of the smoke-derived compound 3-methyl- $2 \mathrm{H}$ furo[2,3-c]pyran-2-one, and its potential as a pre-conditioning agent. Field Crops Res. 98:98-105. 